\title{
ЕЛЕКТРОННЕ ДЕКЛАРУВАННЯ У СИСТЕМІ ЗАБЕЗПЕЧЕННЯ ФІНАНСОВОГО КОНТРОЛЮ ОСІБ, УПОВНОВАЖЕНИХ НА ВИКОНАННЯ ФУНКЦІЙ ДЕРЖАВИ ТА МІСЦЕВОГО САМОВРЯДУВАННЯ
}

Малиновська Н.Л., канд. іст. наук, Інститут державного управління, Чорноморський національний університет імені Петра Могили, м. Миколаїв, Україна.

Непомнюща $\boldsymbol{A} . \boldsymbol{\Gamma}$., головний спеціаліст відділу управління персоналом та організаційної роботи апарату Баштанської районної державної адміністрації Миколаївської області, м. Баштанка, Украіна.

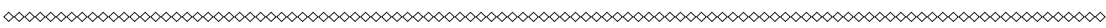

У статті розглянуто електронне декларування як прояв технічної допомоги у розширенні можливостей держави щзодо посилення заходів фінансового контролю осіб, уповноважених на виконання державних та інших, прирівняних до них функиій; проаналізовано функиіональність електронного декларування у системі фінансового контролю осіб, уповноважених на виконання функиій держави та місиевого самоврядування; узагальнено практику здійснення заходів фінансового контролю осіб, уповноважених на виконання функиій держави та місиевого самоврядування на прикладі Баштанської районної державної адміністрації Миколаївської області.

Охарактеризовано сутність, зміст та изілі електронного декларування, простежено еволюиію розуміння та технологічного втілення изього прочесу в деяких країнах. Підкреслено, щзо електронне декларування представляс собою оприлюднення інформачії про свої доходи, майно, цінні папери, активи, інші корпоративні права, фінансові зобов'язання, видатки, правочини тощзо. Його правове регулювання здійснюється Законом України «Про запобігання корупиії» від 14 жовтня 2014 року, який визначає правові й організачійні за- 
сади функціонування системи запобігання корупиії в Украӥні, зміст i порядок застосування превентивних антикорупційних механізмів, правила щуодо усунення наслідків корупційних правопорушень.

Обгрунтовано, що система електронного декларування $\epsilon$ iнструментом, який здатний підвищити ефективність $і$ керованість нашої держави, адже така система сприятиме усуненню корупщійних ризиків у роботі державних службовців, позитивно вплине на ӥхню роботу й дасть змогу підвищити їхній авторитет.

Проаналізовано функиіональність електронного декларування у системі фінансового контролю осіб, уповноважених на виконання функиій держави та місиевого самоврядування. Досліджено, шуо фінансовий контроль здійснюється з використанням специфічних організаційно-правових форм і методів державними органами та спрямований на забезпечення фінансової дисципліни публічними службовияли, на виявлення правопорушень і вжиття заходів впливу щүодо порушників, на виявлення причин і умов, щуо сприяють цүим правопорушенням, та на вжиття заходів до їх усунення.

Виокремлено заходи щзодо фінансового контролю публічних осіб: перевірка електронних декларацій; моніторинг способу життя декларантів; спеціальна перевірка кандидатів на певні посади; перевірка на доброчесність; контроль за забезпеченням відкритості інформачії; контроль за відкритістю діяльності органів державної влади.

Узагальнено практику здійснення заходів фінансового контролю осіб, уповноважених на виконання функцій держави та місиевого самоврядування (на прикладі Бамтанської районної державної адміністращії Миколаївської області). 3 'ясовано, щзо в Баштанській райдержадміністрачії відповідальною особою з питань запобігання та виявлення корупиії визначено завідувача сектора взаємодії $з$ правоохоронними органами, оборонної та мобілізаційної роботи апарату райдержадміністрачіï, до завдань та обов 'язків якого відносяться питання, пов'язані з фінансовим контролем державних службовиів райдержадміністрації.

Проведено аналіз своєчасності подання державними службовиями апарату райдержадміністрації та їі структурних підрозділів 
декларацій осіб, уповноважених на виконання функиій держави у 2017-2019 роках. Зроблено висновок, щуо аналіз фінансового контролю державних службовиів Бамтанської райдержадміністрації показав чітко сформовану схему дій для перевірки електронних декларацій та налагоджену співпращюю органів державної влади щэодо оперативного реагування на порушення вимог законодавства.

Зазначено, що запуск нового режиму декларування публічних службовиів було визнано значним кроком вперед, а сама система декларування вважається однією із найбільи прогресивних у світі. Одночасно із ичи, впровадження електронного декларування на практиці показало ряд суттєвих викликів, які можуть впливати на дієвість иього інструменту та його ефективність у подоланні корупиії в Україні.

Підкреслено, щзо система електронного декларування загалом може принести очікуваний результат лише тоді, коли на практиизі буде належно функціонувати кожна з ї складових: існуватиме якісна нормативно-правова база; реєстр декларацій безперешкодно та належно працюватиме; суб'єкти декларування матимуть достатні знання вимог декларування та розумітимуть його иілі; НАЗК повночінно та об' єктивно виконуватиме свої повноваження; правоохоронні органи будуть ефективно проводити досудові розслідування виявлених правопорушень.

Ключові слова: електронне декларування; електронна декларація; фінансовий контроль; особи, уповноважені на виконання функиій держави та місиевого самоврядування; Баштанська районна державна адміністрація Миколаївської області.

Постановка проблеми у загальному вигляді. Впровадження декларацій про доходи і майно публічних посадових осіб закріплено в Конвенції Організації Об'єднаних Націй проти корупції (ст. 8) [6], у ряді документів Світового банку, Організації економічного співробітництва і розвитку, в інших міжнародних інститутах. Проблемність ситуації полягає в тому, що широкі повноваження та влада, якими наділені особи, уповноважені на виконання функцій держави та місцевого самоврядування, за відсутності ефек- 
тивних методів контролю, є джерелом корупційних ризиків, що у свою чергу підриває довіру населення до влади, негативно сприймається світовим співтовариством та призводить до економічних та інших злочинів. Актуальність теми дослідження підсилюється і необхідністю налагодження дієвого контролю за функціонуванням системи електронного декларування і як засобу фінансового контролю, і як публічного обов'язку посадових осіб, і як інструменту формування відповідальної державницької свідомості та позиції осіб, уповноважених на виконання функцій держави та місцевого самоврядування. Отже, спробуємо розглянути електронне декларування як прояв технічної допомоги у розширенні можливостей держави щодо посилення заходів фінансового контролю осіб, уповноважених на виконання державних та інших, прирівняних до них функцій.

Аналіз досліджень і публікацій. Дослідженням наукової проблематики та розробкою основ електронного декларування посадовими особами розглянуто у працях таких науковців, як Беззуб I., Горобчишиної С., Мацокіна А., Тарасенко Н., Федчишина Ю., Черненко І., Шепотової О., Щирської В.; зарубіжний досвід електронного декларування висвітлено у роботах Задираки Н., Ільєнок Т., Ковриженко Д., Лапшина С., Марченко В..; питання громадського контролю за діяльністю органів влади, у тому числі питання декларування доходів та майна висвітлювались у працях Кладченко А., Рябченко Т. Значний внесок у розвиток теорії державного фінансового контролю зроблено економістами Давидовою Т., Новак А., Шевчук О., Томіною О.; в межах публічної служби увагу фінансовому контролю за діяльністю державних службовців висвітлено у працях Піхоцького В., Дікань Л., Шешотової О., Щирської В. Нормативно-законодавче та інформаційне забезпечення електронного декларування висвітлюється на офіційних сайтах НАЗК, сайтах обласних державних та районних державних адміністраціях.

Але з'являються нові проблемні питання та виникають нові потреби для оптимізації фінансового контролю та моніторингу способу життя високопосадовців на підставі системи електронного декларування. 
Формулювання цілей статті (постановка завдання). В процесі дослідження було поставлено наступні завдання:

- проаналізувати функціональність електронного декларування у системі фінансового контролю осіб, уповноважених на виконання функцій держави та місцевого самоврядування;

- узагальнити практику здійснення заходів фінансового контролю осіб, уповноважених на виконання функцій держави та місцевого самоврядування на прикладі Баштанської районної державної адміністрації Миколаївської області.

Виклад основного матеріалу дослідження. Декларування доходів високопосадовців країн світу стало звичайною практикою останні десятиліття, оскільки неконтрольованість збагачення незаконним шляхом тягне за собою цілу низку ризиків, як для конкретної країни, так і світового співтовариства $[1,2,5]$.

Вбачається, що декларування доходів сприяє виконанню наступних завдань: підвищенню прозорості і довіри громадян до керівництва держави за допомогою обнародування інформації про доходи та майно державних службовців, з тим щоб продемонструвати, що їм немає чого приховувати; наданню допомоги керівникам державних установ у попередженні конфлікту інтересів між їх співробітниками і у вирішенні таких ситуацій, коли вони виникають, для забезпечення сумлінності серед співробітників їх установ; моніторингу змін матеріального добробуту державних службовців, з тим щоб запобігти зловживанням з їх боку і оберегти їх від несправедливих звинувачень, а також встановити повний масштаб неправомірного збагачення та іншої незаконної діяльності $[4,7,9]$

Цілі системи декларування доходів визначають наступним чином.

1. Контроль відносно конфліктів інтересів. У Конвенції Організації Об'єднаних Націй проти корупції [6] прямо згадується можливість «колізії інтересів» як основний критерій визначення інформації, що підлягає декларуванню. Це відображає факт, що контроль за конфліктами інтересів $є$ найбільш поширеною метою використання декларацій державних посадових осіб. Можна сказати, що попередження конфліктів інтересів - вузька область розгляду питання про 
те, чи може той або інший інтерес впливати на виконання посадових обов'язків. В той же час, існує і ширша стурбованість з приводу підзвітності державного сектора у зв'язку з більш загальною можливістю оцінки діяльності державних посадових осіб, включаючи їх потенційні особисті мотиви.

2. Транспарентність і підзвітність державного сектора. Разом 3 попередженням конфліктів інтересів найбільш поширеними заявленими цілями системи декларування $є$ ширша турбота про транспарентність, підзвітність державних службовців, довіра і професійна етика. Ці цілі зовсім не протирічать одна одній і відображають політичний акцент, який робиться в тій або іншій системі. 3 історичної точки зору, право подачі запитів уряду розширювалося і породило ширше право на доступ до інформації, якою володіють органи державного управління. Коли громадськості надається доступ до змісту декларацій державних посадових осіб, даний інструмент, по суті, розширює право на доступ до інформації (або свободу інформації, як це право часто називають) про приватне життя державних посадових осіб [4].

Мабуть, сильніший наголос на попередженні конфліктів інтересів робиться, наприклад, в Сполученому Королівстві Великобританії з його «небажанням вводити вимоги про розкриття особистих і сімейних доходів і активів, причому причина цього полягає в бажанні уникнути вторгнення в приватне життя, яке мають на увазі такі вимоги. Підхід Великобританії заснований на передумові про те, що всі державні посадові особи повинні декларувати будь-які матеріальні і навіть нематеріальні інтереси, відносно яких інші можуть обгрунтовано запідозрити вплив на діяльність посадових осіб. Транспарентність і підзвітність - ключові питання британської системи» (VilloriaMendieta, 2005, стор. 18) [4].

У США дещо більше значення надається загальній підзвітності і професійній етиці. Судячи з усього, в Центральній і Східній Свропі вимоги про підвищення транспарентності самі по собі стали одним 3 визначальних чинників (на додаток до умов, СС, що пред'являється) в розповсюдженні систем декларування доходів державними службовцями. 
Ще одна мета, яка часто заявляється або мається на увазі в системах декларування доходів, полягає в перевірці законності доходів і матеріального положення. Міжнародними стандартами не встановлюється безпосереднього зв'язку між декларуванням і необхідністю моніторингу активів державних посадових осіб. Окрім попередження конфліктів інтересів і підзвітності в державному сектоpi, держави зазвичай прагнуть встановити який-небудь контроль за доходами всіх, а не тільки окремих громадян, що проживають в них.

В той же час, в деяких країнах домінує ідея про те, що декларації державних посадових осіб повинні служити особливим інструментом контролю матеріального положення. У таких випадках панує думка про те, що державні посадові особи повинні піддаватися серйознішій перевірці, ніж населення в цілому $[7,8,9]$.

Еволюція сучасних систем декларування доходів державними посадовими особами почалася, за винятком декількох ранніх епізодів, після Другої світової війни (Burdescu et al., 2009, Figure 1, p. 29). У Сполучених Штатах Америки розширення складу уряду і періодично виникаючі скандали, пов'язані з корупцією, створили стимул для нових ініціатив щодо зміцнення професійної етики державних службовців. Одне 3 перших політичних висловлювань щодо необхідності введення вимог публічного розкриття особистої фінансової інформації деяких державних посадових осіб федерального рівня прозвучало в посланні президента Гарі Трумена Конгресу в 1951 році: «Враховуючи всі питання, які піднімаються в наші дні з приводу непідкупності і чесності державних посадових осіб, думаю, ми всі готові представити факти відносно наших доходів на розгляд громадськості» [4].

Різні чинники перешкодили впровадженню системи декларування доходів та активів державними посадовими особами на федеральному рівні в 1950-х роках. Лише у 1965 році президент Ліндон Джонсон ввів вимогу про те, щоб федеральні посадові особи розкривали стан своїх приватних фінансів органам державної влади (Mackenzie and Hafken, 2002, pp. 24-26). Для ухвалення конгресом США Закону про етику в уряді в 1978 році знадобилися «Уотергейтський» та інші скандали. Цей Закон діє і до цього дня, він вимагає від 
урядовців рангом вище певного рівня у всіх трьох гілках федеральної влади публічного розкриття докладної фінансової інформації [4].

Ще в 1950-х роках в США робилися певні ініціативи щодо впровадження публічного розкриття фінансової інформації на рівні окремих штатів. За станом на 1969 рік, 11 штатів вимагали такого публічного розкриття (Anechiarico and Jacobs. 1996, pp. 47-48). Розповсюдження практики введення подібних вимог для державних посадових осіб почало досягати серйозних масштабів в 1970-х роках. Зростання обхвату посадових осіб і масштабу інформації, що підлягає розкриттю, привело до численних судових тяжб у зв'язку 3 тим, що вимоги про розкриття інформації роблять замах на право на конфіденційність приватного життя. У США хвиля подібних судових розглядів досягла свого піку в 1970-і роки, та все ж підсумком всіх цих справ стало загальне визнання повноваження держави ввести обов'язкове розкриття інформації (Rohr, 1998, pp. 44-45).

У більшості країн Західної Свропи практика розкриття державними посадовими особами їх доходів, активів і фінансових інтересів розповсюдилася пізніше. Сдиним виключенням стало Сполучене Королівство Великобританії - країна, де Закон про запобігання корупції був ухвалений ще в 1889 році. Історичні дані свідчать про те, що парламент в цілому з небажанням йшов на введення правил розкриття інформації. Навіть заснований в 1969 році спеціальний комітет дійшов висновку про те, що в створенні реєстру інтересів немає ніякої потреби завдяки переконаності в честі і самодисципліні кожного з членів парламенту. Проте в 1974 році палатою общин був введений Реєстр інтересів. Але навіть після 1974 року питання про те, які саме інтереси мають відношення до справи і підлягають декларуванню або реєстрації, залишалося до певної міри відкритим i, на думку деяких, повинен був визначатися на розсуду самих членів парламенту (Doig, 1996, pp. 42, 44) [4,8,9,24].

При впровадженні декларування країни аналізують існуючі передумови і можливості, включаючи учасників процесу, на яких можна покластися (відповідальних керівників, чесних державних службовців, активні 3МI), існуючу нормативно-правову базу (систему збору податків і реєстрації майна, інші державні реєстри, існуючу норматив- 
но-правову базу), а також обмежуючі чинники (дефіцит державних коштів, відсутність політичної волі до боротьби з корупцією та низьку дисципліна у сфері державної служби). Країни також визначають оптимальні функціональні рамки в контексті правових, фінансових, кадрових і інших можливостей для створення системи декларування.

На думку багатьох науковців [3, 23, 26], чинне законодавство України не визначає загального поняття «фінансовий контроль публічної служби», окремі елементи цього явища містять: розділ 7 Закону України «Про запобігання корупції» [19], стаття 25 Закону України «Про державну службу» [13], стаття 13 «Про службу в органах місцевого самоврядування» [18].

Метою державного фінансового контролю є виявлення відхилень від прийнятих норм та стандартів, порушень принципів законності, ефективності і економії витрачання матеріальних ресурсів на найбільш ранній стадії для того, щоб мати можливість вжити коригувальних заходів, а в окремих випадках - притягти винних до відповідальності, отримати компенсацію за заподіяну шкоду або здійснити заходи щодо запобігання або скорочення подібних порушень у майбутньому [23, 26].

Фінансовий контроль розуміється як врегульована правовими нормами діяльність, що здійснюється 3 використанням специфічних організаційно-правових форм і методів державними органами та спрямована на забезпечення фінансової дисципліни публічними службовцями, на виявлення правопорушень і вжиття заходів впливу щодо порушників, на виявлення причин і умов, що сприяють цим правопорушенням, та на вжиття заходів до їх усунення.

На цей час в Україні на законодавчому рівні передбачено наступні шляхи контролю за доходами та видатками публічних осіб, уповноважених на виконання функцій держави:

1) Законом України «Про запобігання корупції» [19] та Податковим кодексом України [11] передбачено електронне декларування доходів осіб, уповноважених на виконання функцій держави або місцевого самоврядування, та прирівняних до них;

2) Законом України «Про запобігання корупції»[19] створено центральний орган виконавчої влади України зі спеціальним ста- 
тусом, який забезпечує формування та реалізує державну антикорупційну політику, зокрема перевірки декларацій державних службовців і стилю їх життя, розкриття будь-якої інформації з приводу фактів корупції чи зловживання посадою;

3) Законом України «Про запобігання та протидію легалізації (відмиванню) доходів, одержаних злочинним шляхом, або фінансуванню тероризму» [20] забезпечено національну безпеку шляхом визначення правового механізму протидії легалізації (відмиванню) доходів, одержаних злочинним шляхом, фінансуванню тероризму та фінансуванню розповсюдження зброї масового знищення, а також формування загальнодержавної джерельної аналітичної бази даних для надання правоохоронним органам України та іноземних держав можливості виявляти, перевіряти і розслідувати злочини, пов’язані з відмиванням коштів та іншими незаконними фінансовими операціями.

Отже, система електронного декларування як складова фінансового контролю осіб, уповноважених на виконання функцій держави та місцевого самоврядування, стала реальністю після прийняття нової редакції антикорупційного закону - Закону «Про запобігання корупції» від 14 жовтня 2014 року [19]. Цей закон приймався під тиском громадських антикорупційних організацій і активно підтримувався країнами Свропейського Союзу, США як потужний антикорупційний запобіжник (відомо, що прийняття законодавства про електронне декларування було однією з умов лібералізації візового режиму між Україною і (С).

Згідно з Законом від 14 жовтня 2014 року, замість паперових декларацій про доходи, витрати і зобов'язання фінансового характеру було запроваджено значно повніші електронні декларації про доходи, витрати, майно, інші активи (у тому числі готівкові заощадження, цінні речі), фінансові зобов'язання посадовців, депутатів, членів їхніх сімей. Якщо паперові декларації зберігалися в особових справах у кадрових підрозділах органів (щоб зберегти їх зміст в таємниці від інших співробітників, декларації часто заклеювали в конверти), то, за законом від 14 жовтня 2014 року, е-декларації розміщено в мережі Інтернет у спеціальному Реєстрі декларацій і кожен бажаючий може ознайомитись з інформацією про посадовця та депутата 
На підставі моніторингу процесу електронного декларування, а також аналізу планово-звітної документації, статистичних даних Баштанської РДА, звітів голови Баштанської РДА [22], інформаційних матеріалів 3 офіційного сайту РДА та іншої документації, матеріалів громадського контролю, відкритих джерел інформації щодо виконання посадовими особами свого публічного обов'язку у вигляді заповнення декларацій, протоколів нарад та круглих столів, анкетування та бесід з співробітниками Баштанської РДА було проведено дослідження на базі Баштанської районної державної адміністрації Миколаївської області з метою з'ясування проблемних питань 3 можливістю виправлення ситуації та ії удосконалення.

Оскільки спосіб життя та доходи державних посадовців привертають до себе підвищену увагу, а іноді і напряму призводять до корупційних правопорушень, це питання є досить актуальним та небезпечним, як у плані довіри до влади, так і у скоєнні економічних злочинів.

Незважаючи на нормативно-правове та організаційно-технічне забезпечення, практичний аспект електронного декларування має свої проблеми, а тому потребує додаткового вивчення.

В ході дослідження вивчались такі питання: дисципліна виконання зобов'язань учасників електронного декларування; існуючі претензії та пропозиції щодо удосконалення або спрощення процедури електронного декларування; стан обізнаності та розуміння необхідності впровадження електронного декларування як показника фінансового контролю.

Як бачимо зі «Звіту про здійснення Баштанською райдержадміністрацією покладених на неї повноважень у 2019 році та стан розвитку території» [22] до складу Баштанського району входить Баштанська міська рада та 10 сільських рад (Доброкриничанська, Срмолівська, Інгульська, Кашперо-Миколаївська, Костичівська, Лоцкинська, Лук'янівська, Мар'ївська, Привільненська, Старогороженська), загалом 60 населених пунктів.

На території району утворено 2 об'єднані територіальні громади - Баштанську міську, до складу якої увійшли населені пункти Баштанської міської та 8 сільських рад (Добренської, Новоіванів- 
ської, Новопавлівської, Новосергіївської, Пісківської, Плющівської, Христофорівської та Явкинської), а також Лоцкинську сільську, до складу якої увійшли 3 населених пункти Лоцкинської та Новоолександрівської сільських рад.

На погодженні в Міністерстві регіонального розвитку знаходиться проект Перспективного плану з 4 об'єднаних територіальних громад у межах району: Баштанської ОТГ (у теперішньому стані), Лоцкинської ОТГ (у складі Лоцкинської, Новоолександрівської та Доброкриничанської сільських рад), Інгульської ОТГ (у складі Інгульської, Мар'ївської та Костичівської сільських рад) та Привільненської ОТГ (у складі Привільненської, Кашперо-Миколаївської, Лук’янівської, Старогороженської та Єрмолівської сільських рад). У разі погодження Мінрегіоном та затвердження Кабінетом Міністрів України територія району в майбутньому буде повністю складатися із об'єднаних громад.

Станом на 31.12.2019 гранична чисельність працівників Баштанської райдержадміністрації складає 107,5 штатних одиниць, 3 них: державних службовців - 99.

\section{Структура і чисельність Баштанської районної державної} адміністрації. Керівництво та апарат.

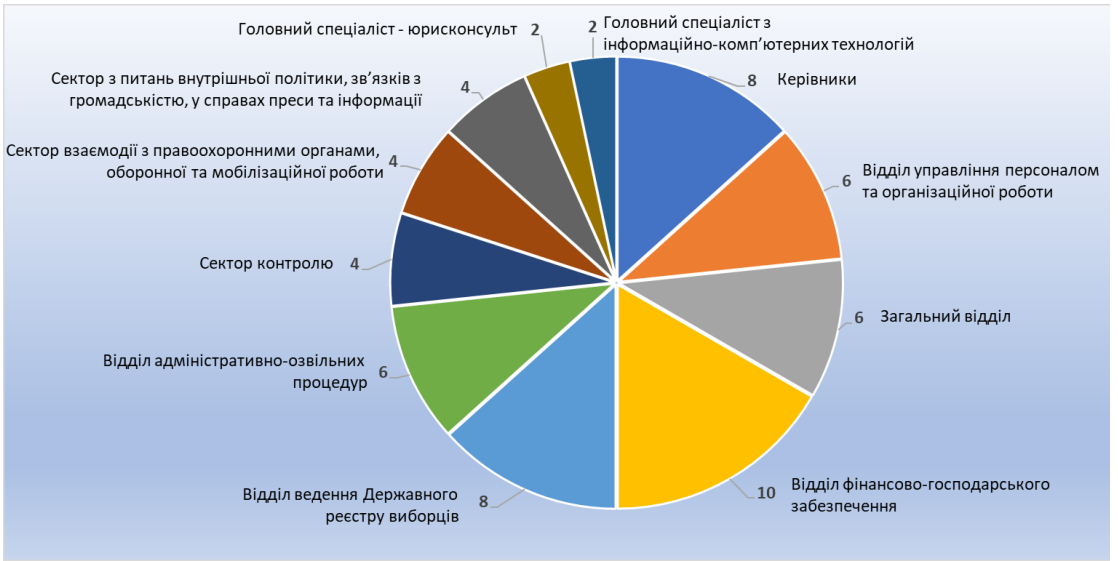


На звітну дату у райдержадміністрації налічується 16 вакантних посад, 3 них: 2 посади керівного складу (перший заступник голови райдержадміністрації - вакансія з 12.12.2019, заступник голови райдержадміністрації - вакансія з 14.05.2015, 1 посада державної служби категорії «Б» та 13 посад категорії «В»).

Відповідно до статті 23 Закону України «Про державну службу», постанови Кабінету Міністрів України від 25.03.2016 №246 «Про затвердження Порядку проведення конкурсу на зайняття посад державної служби» у райдержадміністрації забезпечується дотримання вимог щодо оприлюднення інформацій про вакантні посади державної служби, оголошення про проведення конкурсу та результати конкурсу розміщено на офіційних веб-сайтах Нацдержслужби та райдержадміністрації.

Протягом 2019 року проведено 2 засідання конкурсної комісії апарату райдержадміністрації. Конкурси на зайняття вакантних посад не відбулися у зв'язку з відсутністю поданих заяв від кандидатів.

Відповідно до розпорядження голови райдержадміністрації від 01.10.2019 №25-рк, наказу керівника апарату райдержадміністрації від 01.10.2019 №34-нк у жовтні-листопаді 2019 року забезпечено організацію проведення оцінювання результатів службової діяльності державних службовців.

Розпорядженням голови райдержадміністрації від 29.11.2019 №30-рк, наказу керівника апарату райдержадміністрації від 29.11.2019 №41-нк затверджено висновки щодо результатів оцінювання службової діяльності державних службовців категорій «Б» $\mathrm{i} \ll \mathrm{B} »$.

Протягом 2019 року свій професійний рівень за програмами постійно діючих та короткотермінових семінарів 3 видачею відповідних посвідчень підвищили 40 державних службовців Баштанської райдержадміністрації, з них: 33 - у Миколаївському обласному центрі перепідготовки та підвищення кваліфікації працівників органів державної влади, 6 - у Одеському регіональному інституті державного управління Національної академії державного управління при Президентові України, 1 - у На- 
ціональній академії державного управління при Президентові України м. Київ.

Відділ управління персоналом та організаційної роботи апарату райдержадміністрації брав участь у Всеукраїнському конкурсі «Кращі практики управління персоналом», у якому здобув I місце у номінації «Краща практика управління талантами в державному органі».

3 метою проведення інформаційно-роз'яснювальної роботи щодо підвищення привабливості державної служби проводиться агітаційна робота серед державних службовців щодо вступу на навчання до Одеського РІДУ НАДУ та Чорноморського державного університету імені Петра Могили для здобуття освіти у галузях «Державне управління» та «Державна служба». Станом на 01 січня 2020 року 1 державний службовець райдержадміністрації навчається у Чорноморському державному університеті імені Петра Могили за спеціальністю «Публічне управління та адміністрування» та 3 - в Одеському регіональному інституті державного управління Національної академії державного управління при Президентові України [22].

Одним із пріоритетних завдань Баштанської райдержадміністрації є дотримання чинного антикорупційного законодавства.

В Баштанській райдержадміністрації відповідальною особою 3 питань запобігання та виявлення корупції визначено завідувача сектора взаємодії з правоохоронними органами, оборонної та мобілізаційної роботи апарату райдержадміністрації, до завдань та обов'язків якого відносяться:

1) розроблення та проведення заходів щодо запобігання корупційним правопорушенням, а також здійснення контролю за їх проведенням;

2) надання структурним підрозділам райдержадміністрації та їх окремим працівникам, виконкомам міської та сільських рад роз'яснення щодо застосування антикорупційного законодавства;

3) вжиття заходів щодо виявлення конфлікту інтересів та сприяння його усуненню, контроль за дотриманням вимог законодавства щодо врегулювання конфлікту інтересів, а також виявлення 
сприятливих для вчинення корупційних правопорушень ризиків в діяльності посадових і службових осіб райдержадміністрації, надання голові райдержадміністрації пропозиції щодо усунення таких ризиків;

4) надання допомоги в заповненні електронних декларацій працівників апарату райдержадміністрації;

5) взаємодія з підрозділами (особами) з питань запобігання та виявлення корупції структурних підрозділів райдержадміністрації, інших центральних органів виконавчої влади, органів місцевого самоврядування, підприємств, установ та організацій, спеціально уповноваженими суб'єктами у сфері протидії корупції.

Слід зазначити, що початком роботи системи електронного декларування є 01 вересня 2016 року [16]. Щорічні декларації за 2015 рік подавали особи, які станом на 01.09.2019 займали згідно зі статтею 50 Закону України «Про запобігання корупції» [19] відповідальне та особливо відповідальне становище (державні службовці, які обіймають керівні посади), в термін до 30 жовтня 2016 року.

Під час роботи з Сдиним державним реєстром декларацій осіб, уповноважених на виконання функцій держави або місцевого самоврядування [28] виникали збої в системі, незручність внесення даних. В передостанні дні подачі декларацій, а саме 27-28 жовтня, зафіксовано збої в роботі сайту електронного декларування. Декларантам згідно запитів до НАЗК своєчасно надавалась технічна підтримка та працювала гаряча лінія [17].

Встановлено, що 12 державних службовців Баштанської райдержадміністрації, віднесених до категорії «Б» посад державної служби, своєчасно подали електронні декларації та успішно пройшли перший етап декларування.

Нами проведено аналіз своєчасності подання державними службовцями апарату райдержадміністрації та іiі структурних підрозділів декларацій осіб, уповноважених на виконання функцій держави у 2017-2019 роках. 
Перевірка факту подання суб'сктами декларування апарату та структурних підрозділів Баштанської райдержадміністрації декларацій осіб, уповноважених на виконання функцій держави або місцевого самоврядування за 2017-2019 роки

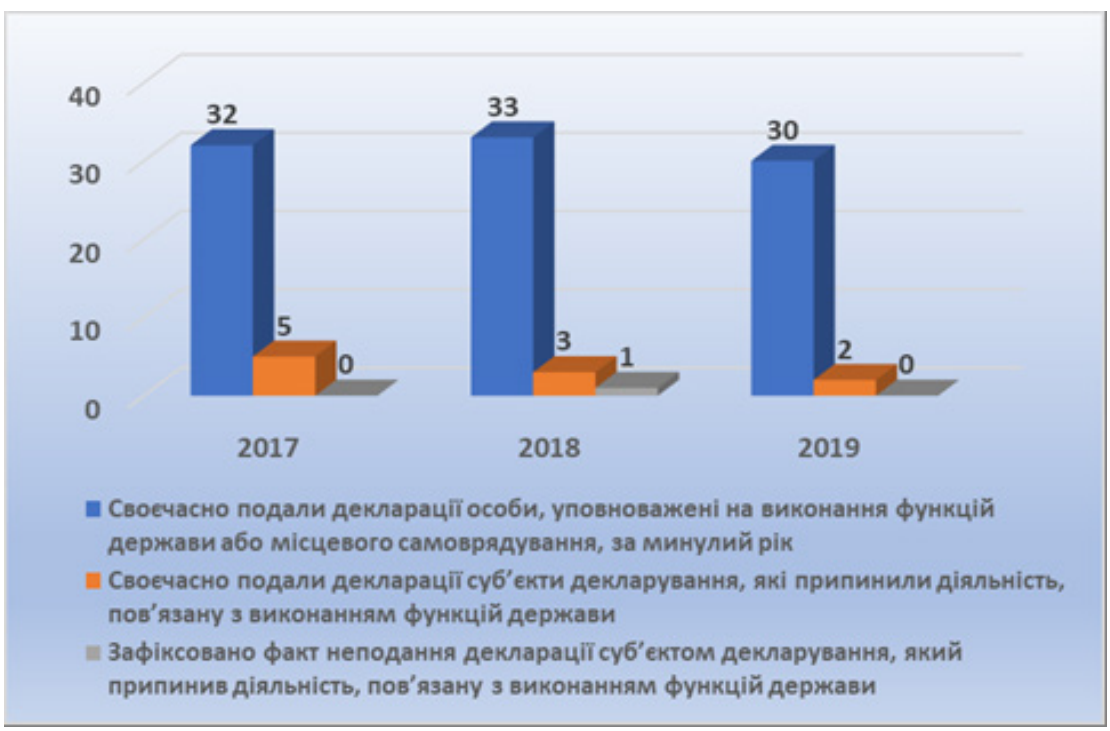

Звертаємо увагу на те, що в Баштанській райдержадміністрації відділ управління персоналом та організаційної роботи забезпечує виконання вимог Порядку перевірки факту подання суб' єктами декларування декларацій відповідно до Закону та повідомлення Національного агентства $з$ питань запобігання корупції про випадки неподання чи несвоєчасного подання таких декларацій, затвердженого рішенням Національного агентства від 06 вересня 2016 року №19 [21].

Значна увага приділяється особам, які припинили діяльність, пов'язану з виконанням функцій держави або місцевого самоврядування. Вони зобов'язані наступного року після припинення діяльності подавати в установленому порядку декларацію особи, уповноваженої на виконання функцій держави або місцевого самоврядування, за минулий рік. Відділом управління персоналом Баш- 
танської райдержадміністрації вчасно попереджено та ознайомлено державних службовців з вимогами законодавства в усній та письмовій формі.

Згідно з актом перевірки факту подання суб'єктами декларування Баштанської райдержадміністрації декларацій відповідно до Закону України «Про запобігання корупції» у квітні 2018 року встановлено факт неподання електронної декларації однією особою, яка звільнена у 2017 році. Перевірку здійснено шляхом пошуку та перегляду інформації в публічній частині Єдиного державного реєстру декларацій осіб, уповноважених на виконання функцій держави або місцевого самоврядування, на офіційному веб-сайті Національного агентства з питань запобігання корупції - https://public.nazk.gov.ua $[12,16,17,21$,$] .$

Так як дане зобов'язання є чинним після звільнення, то відділ управління персоналом Баштанська райдержадміністрація упродовж трьох днів 3 дня виявлення факту неподання декларації надав повідомлення Національному агентству з питань запобігання корупції згідно з додатком 1 до Порядку перевірки факту подання суб'єктами декларування декларацій [21] відповідно до Закону України «Про запобігання корупції» [19] та повідомлення Національного агентства $з$ питань запобігання корупції про випадки неподання чи несвоєчасного подання таких декларацій. Спільно з завідувачем сектору взаємодії з правоохоронними органами, оборонної та мобілізаційної роботи апарату райдержадміністрації надіслано лист сектору взаємодії з правоохоронними органами та оборонної роботи апарату Миколаївської облдержадміністрації про факт неподання декларації суб'єктом декларування.

Національне агентство 3 питань запобігання корупції письмово повідомляє про факт неподання декларації спеціально уповноваженим суб'єктам у сфері протидії корупції. Статтею 1 Закону України «Про запобігання корупції» [19] передбачено, що Національна поліція [14] є спеціально уповноваженим суб'єктом у сфері протидії корупції.

Структурним підрозділом Національної поліції України - управлінням захисту економіки в Миколаївській області перевіряються 
факти порушення вимог фінансового контролю відповідно до Закону України «Про запобігання корупції» [19] суб'єктами декларування Миколаївської області.

Управлінням захисту економіки в Миколаївській області відповідно до покладених завдань та повноважень вживаються системні заходи щодо запобігання, виявлення та припинення корупційних проявів в діяльності суб'єктів владних повноважень, а саме посадових осіб державних установ, осіб уповноважених на виконання функцій держави та місцевого самоврядування.

Здійснюється контроль за дотриманням вимог Закону України «Про запобігання корупції» [19] та інших нормативних актів, що регулюють стримання та вжиття заходів по відношенню до корупційних проявів у діяльності суб'єктів визначених в статті 3 даного Закону.

На виконання пунктів 3, 5 частини першої статті 23 Закону України «Про Національну поліцію» [14], статей 53, 60 Закону України «Про запобігання корупції» [19] райдержадміністрація надала інформацію та пакет документів на запит Національної поліції України.

Райдержадміністрацію проінформовано, що відповідно до пункту 3 частини першої статті 23 Закону України «Про Національну поліцію» [14] поліція відповідно до покладених на неї завдань, зокрема вживає заходів 3 метою виявлення кримінальних, адміністративних правопорушень, припиняє виявлені кримінальні та адміністративні правопорушення. Згідно статті 33 цього Закону встановлено, що поліцейський може опитати особу, якщо існує достатніх підстав вважати, що вона володіє інформацією, необхідною для виконання поліцейських повноважень. Для опитування поліцейський може запросити особу до поліцейського приміщення.

Також статтею 254 КУпАП встановлено, що про вчинення адміністративного правопорушення складається протокол уповноваженою на те посадовою особою органів внутрішніх справ. Основним документом, призначеним для фіксації юридичного факту адміністративного правопорушення, є протокол про адміністративне правопорушення. 
Управління захисту економіки в Миколаївській області задокументувало адміністративне правопорушення та складено протокол щодо порушення термінів подачі електронної декларації після звільнення відносно вищевказаної особи, який спрямовано до Баштанського районного суду для вирішення питання. За несвоєчасне подання без поважних причин декларації в Кодексі України про адміністративні правопорушення передбачена відповідальність у вигляді штрафу від 850 до 1700 грн.

Відстежено, що інформацію про порушника занесено до Єдиного державного реєстру осіб, які вчинили корупційні або пов'язані 3 корупцією правопорушення.

Згідно судового рішення особу притягнено до адміністративної відповідальності за частиною першою статті 172-6 КУпАП та накладено стягнення у виді штрафу в розмірі 850 гривень. Також зафіксовано, що дана особа подала електронну декларацію після звільнення за 2017 рік 31 січня 2019 року.

Статтею 25 Закону України «Про державну службу» [13] передбачено, що особа, яка бажає взяти участь у конкурсі, подає в установленому порядку до конкурсної комісії відповідні документи, серед яких - декларація особи, уповноваженої на виконання функцій держави або місцевого самоврядування за минулий рік.

Протягом 2017-2019 років проведено 15 конкурсів на зайняття вакантних посад державної служби в райдержадміністрації та іiі структурних підрозділах, 13 конкурсів не відбулись у зв'язку із відсутністю поданих заяв від осіб, які б виявили бажання взяти участь у конкурсах. Конкурсною комісією райдержадміністрації встановлено факт подання 17 особами електронних декларацій, як кандидатів на зайняття посад державної служби. Перед призначенням на посаду державної служби 15 переможців конкурсу подали декларацію особи, уповноваженої на виконання функцій держави або місцевого самоврядування.

Відповідно до статті 31 Закону України «Про державну службу» [13] рішення про призначення або відмову у призначенні на посаду державної служби переможця конкурсу приймається за результатами перевірки відповідно до Закону України «Про очищення 
влади» та за результатами спеціальної перевірки відповідно до Закону України «Про запобігання корупції». Саме декларація, яка була подана переможцем конкурсу, підлягає перевірці.

Слід зазначити, що спеціальна перевірка стосується осіб, які претендують на зайняття посад, які передбачають зайняття відповідального або особливо відповідального становища, та посад 3 підвищеним корупційним ризиком, перелік яких затверджено Національним агентством з питань запобігання корупції.

За результатами перевірок відповідно до Закону України «Про очищення влади» [15] 7 осіб призначено на посади категорії «В» державної служби, як переможців конкурсу. 2 особи, які пройшли перевірку, відмовились від призначення на посаду за власним бажанням.

За результатами спеціальної перевірки відповідно до Закону України «Про запобігання корупції» [19] призначено 6 осіб на посади категорії «Б» державної служби, які передбачають зайняття відповідального або особливо відповідального становища.

Хочемо зазначити, що 15 поданих декларації пройшли перевірку та за результатами перевірки встановлено, що до всіх осіб, не застосовуються заборони, передбачені частиною третьою/четвертою статті 1 Закону України «Про очищення влади» [15] та не виявлено інформації, що перешкоджає зайняттю посади, яка передбачає зайняття відповідального, або особливо відповідального становища або посади $з$ підвищеним корупційним ризиком.

3 метою оцінки якості інформаційних та консультативних послуг, які надаються відділом управління персоналом та організаційної роботи апарату райдержадміністрації (відділ управління персоналом), щодо заповнення електронних декларацій у жовтні 2019 року проведено он-лайн опитування державних службовців райдержадміністрації. Опитувальник містив 9 питань 3 варіантами відповідей.

В он-лайн опитуванні взяли участь 16 службовців, які займають посади категорії «Б» та «В» державної служби.

За результатами дослідження встановлено, що 


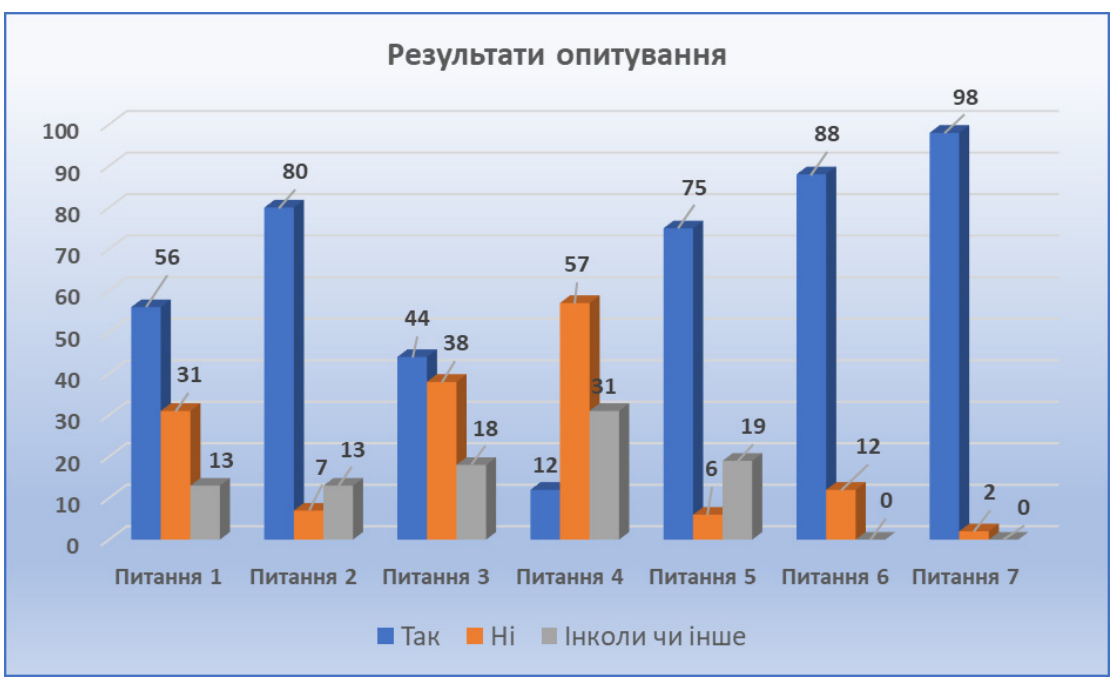

1. При заповненні е-декларацій Ви звертаєтесь до відділу управління персоналом? Відповідь: 50\% державних службовців звертаються за консультацією до відділу управління персоналом при заповненні електронних декларацій.

Щороку 3 працівниками проводяться семінар-навчання 3 питання заповнення декларацій. 3 метою підвищення рівня знань та вдосконалення практики застосування положень антикорупційного законодавства протягом 2018-2019 років державні службовці пройшли підвищення кваліфікації у Миколаївському центрі перепідготовки та підвищення кваліфікації працівників державних установ. При заповненні Е-декларацій використовуються інструкції, роз’яснення та відео-презентації від НАЗК $[16,17,21]$.

2. Чи отримуєте Ви змістовну інформацію на запитання? Відповідь: 80\% опитаних отримали змістовну інформацію на питання від працівників відділу управління персоналом, що є результатом їх компетентності з даної тематики.

3. Чи с необхідність у проведенні навчання з державними служсбовцями РДА щцодо заповнення е-декларацій? Відповідь: 44 \% службовців вважають за необхідне проводити навчання щодо запо- 
внення електронних декларацій, адже на них можна отримати відповіді на актуальні питання, розглядати конкретні приклади, проводити дискусію. Працівники райдержадміністрації пропонують більш детально розглядати на навчаннях розділи декларації щодо майнового стану, земельних питань, уточнення щодо категорії членів родини.

4 Чи виникають у Вас труднощі при заповненні Е-декларацій в Сдиному державному реєстрі декларацій? Відповідь: Лише у 12 \% опитаних виникають труднощі при заповненні електронних декларацій в Реєстрі декларацій. 31 \% декларантів зазначили на певні технічні незручності при роботі з Реєстром. Працівниками відділу управління персоналом завжди акцентується увага на перевантаження Реєстру в останні дні подачі електронних декларацій, надаються рекомендації завчасно проводити дану роботу.

5. Чи с зручною для Вас електронна форма декларацї? Відповідь: Для 75 \% державних службовців електронна форма декларації є зручною, проте для 19 \% опитаних паперовий варіант зручніший. Дане питання вивчено та з'ясовано, що декларанти не мають комп'ютерної техніки для заповнення електронних декларацій вдома, вони витрачають робочий час та техніку для виконання цієї функції.

6. Чи виникають у Вас труднощі з отриманням ЕЦП для nidnису E-декларацій? Відповідь: 88 \% опитаних швидко і зручно отримали ЕЦП за допомогою системи АЦСК Приват24. Для підпису електронних декларацій використовується особистий електронний цифровий підпис (ЕЦП), який потрібно отримати в одному 3 акредитованих центрів сертифікації ключів.

7. Чи задоволені Ви роботою відділу управління персоналом? Відповідь: 98 \% опитаних працівників райдержадміністрації задоволено роботою відділу управління персоналом, що свідчить про компетентність та професіоналізм працівників відділу.

Щодо покращення роботи відділу управління персоналом з заповнення електронних декларацій надійшли пропозиції: на навчаннях розглядати більше прикладів з відео супроводженням; відділу управління персоналом на початку звітного року випускати власний методичний матеріал для державних службовців Баштанської райдержадміністрації. 
Отже, проведений аналіз фінансового контролю державних службовців Баштанської райдержадміністрації показав чітко сформовану схему дій для перевірки електронних декларацій та налагоджену співпрацю органів державної влади щодо оперативного реагування на порушення вимог законодавства.

Висновки. Підсумовуючи викладений матеріал доцільно зазначити, що електронне декларування представляє собою оприлюднення інформації про свої доходи, майно, цінні папери, активи, інші корпоративні права, фінансові зобов'язання, видатки, правочини тощо. Його правове регулювання здійснюється Законом України «Про запобігання корупції» від 14 жовтня 2014 року. Значною перевагою електронного декларування є здатність застосовувати автоматизовані системи обробки даних. Система електронного декларування виконує свою превентивну функцію. Вона вже є дієвим механізмом фінансового контролю посадових осіб, у виявленні та подоланні передумов і наслідків корупції, викритті корупційних діянь та покаранні винних у їх вчиненні.

В Україні удосконалено роботу щодо механізму контролю за своєчасністю подання декларацій - від моніторингу, який здійснюють уповноважені особи НАЗК в органах державної влади та місцевого самоврядування, вручення повідомлень НАЗК суб'єктам декларування, - до складання та направлення обгрунтованих висновків НАЗК до правоохоронних органів.

Важливо ще раз відзначити, що система електронного декларування загалом може принести очікуваний результат лише тоді, коли на практиці буде належно функціонувати кожна з їі складових: існуватиме якісна нормативно-правова база, реєстр декларацій безперешкодно та належно працюватиме, суб'єкти декларування матимуть достатні знання вимог декларування та розумітимуть його цілі, НАЗК повноцінно та об'єктивно виконуватиме свої повноваження, правоохоронні органи будуть ефективно проводити досудові розслідування виявлених правопорушень.

А також, коли громадський контроль буде допомагати викорінювати негативні явища фінансової недоброчесності; засоби масової інформації та засоби масової комунікації сприятимуть інфор- 
маційній та роз'яснювальній роботі, а навчальні та освітні заклади будуть формувати уявлення про державну службу як про високий обов’язок служіння власному народу та державі.

Стаття надійшла до редакції: 08.01.20

\section{ELECTRONIC DECLARATION IN THE SYSTEM OF PROVIDING FINANCIAL CONTROL OF PERSONS AUTHORIZED FOR FUNCTIONING OF STATE AND LOCAL GOVERNMENT}

Natalia Malynovska, $\mathrm{PhD}$ in Historical Sciences, Associate Professor at the Department of Social Work, Management and Pedagogy, Institute of Public Administration, Black Sea National University of Petro Mohyla, Mykolaiv, Ukraine

Alona Nepomniushcha, chief specialist of the department of personnel management and organizational work of the establishment of Bashtanka district state administration of Mykolaiv region, Bashtanka, Ukraine.

The article deals with electronic declaring as a manifestation of technical assistance in empowering the state to strengthen financial control measures for persons authorized to perform state and other functions equivalent to them; the functionality of electronic declaration in the system of financial control of persons authorized to perform the functions of the state and local government is analysed; the practice of implementing measures of financial control of persons authorized to perform the functions of the state and local government on the example of the Bashtanka district state administration of the Mykolaiv region.

The essence, content and purposes of electronic declaration are characterized, and the evolution of understanding and technological implementation of this process in some countries is traced.

It is emphasized that electronic declaration is the disclosure of information about their income, property, securities, assets, other 
corporate rights, financial obligations, expenses, transactions and more. Its legal regulation is implemented by the Law of Ukraine "On Prevention of Corruption" of October 14, 2014, which defines the legal and organizational principles of functioning of the system of prevention of corruption in Ukraine, the content and the procedure of application of preventive anti-corruption mechanisms, rules for elimination of consequences of corruption offenses.

It is concluded that the electronic declaration system is a tool that can improve the efficiency and controllability of our country, since such a system will help eliminate corruption risks in the work of civil servants, positively affect their work and will allow them to increase their authority.

Functionality of electronic declaration in the system of financial control of persons authorized to perform the functions of state and local government is analysed. It has been investigated that financial control is carried out using specific organizational legal forms and methods by public authorities and is aimed at providing financial discipline to public officials, to detect offenses and take measures to influence offenders, to identify the causes and conditions contributing to these offenses, measures to eliminate them.

The measures for financial control of public persons are distinguished: checking of electronic declarations; monitoring of declarants' lifestyle; special screening of candidates for certain positions; integrity check; control over ensuring openness of information; control over openness of activity of state authorities.

The practice of implementation of measures of financial control of persons authorized to perform the functions of the state and local government (on the example of Bashtanka district state administration of Mykolaiv region) is generalized. It is found out that in Bashtanka district state administration responsible for prevention and detection of corruption has been appointed head of the sector of interaction with law enforcement agencies, defense and mobilization work of the apparatus of the state state administration, whose tasks and responsibilities are related to issues of state administration.

The timeliness of filing by state officials of the establishment of the district state administration and its structural subdivisions of the 
declarations of the persons authorized to perform the functions of the state in 2017-2019 is analysed.

It is concluded that the analysis of financial control of civil servants of the Bashtanka district state administration showed a clearly formed scheme of actions for verification of electronic declarations and wellestablished cooperation of public authorities in responding promptly to violations of legislative requirements.

It was noted that the launch of the new regime for declaring public servants was recognized as a significant step forward, and the system of declaring itself is considered one of the most progressive in the world. At the same time, the implementation of electronic declarations in practice has revealed a number of significant challenges that may affect the effectiveness of this tool and its effectiveness in combating corruption in Ukraine.

It is emphasized that the system of electronic declaration in general can produce the expected result only when in practice each of its components will function properly: there will be a high quality legal framework; the register of declarations shall be unimpeded and properly operated; the subjects of the declaration will have sufficient knowledge of the requirements of the declaration and will understand its purpose; NACP will exercise its authority fully and objectively; law enforcement agencies will effectively conduct pre-trial investigations of identified offenses.

Keywords: electronic declaring; electronic declaration; financial control; persons authorized to perform the functions of the state and local government; Bashtanka district state administration of Mykolaiv region.

\section{Received: 08.01.20}




\section{References}

1. Bezzub, I. (2016) Vprovadzhennja elektronnogo deklaruvannja dohodiv derzhposadovciv v Ukraini [The introduction of electronic declaration of income of State officials in Ukraine] [Tekst] / I. Bezzub // Gromadska dumka pro pravotvorennja. - 2016. - № 4. - S. 10-11. [in Ukraine]

2. Chernenko, I. V. (2017) Elektronne deklaruvannja jak novitnii instrument borotby z korupcieju v Ukraini [Electronic declaration as the newest tool of the fight against corruption in Ukraine] [Elektron. resurs] / I. V. Chernenko // Naukovyi visnyk Hersonskogo derzhavnogo universytety. - 2017. - Vypusk № 2. - S. 59-62 - Retrieved from : http://www.lj.kherson.ua/2017/ pravo02/ part_2/18.pdf. [in Ukraine]

3. Davydova, T. O. (2014) Finansovyi kontrol jak zasib protydii korupcii [Financial control as a means of combating corruption] [Elektron. resurs] / T. O. Davidova // Naukovyi visnyk Uzhgorodskogo nacionalnogo universitetu. Serija : Pravo. - 2014. - Vip. 29 (2). - S. 127-130. - [Elektron. resurs]. - Retrieved from : http://nbuv.gov.ua/ UJRN/nvuzhpr_2014_29(2). [in Ukraine]

4. Deklaracii aktivov dlja gosudarstvennyh sluzhashhih: instrument dlja predotvrashhenija korrupcii [Declaration of active for sovereign servants: Korrupcii OECD (2011), Asset Declarations for Public Officials: A Tool to Prevent Corruption]: (Russian version), OECD Publishing. [Elektron. resurs]. Retrieved from : http://dx.doi.org/9789264118799.[in Ukraine]

5. Gorobchishina, S. (2017) E-deklaruvannja: domashne zavdannja antikorupcii [E-declaration: Anti-corruption homework] [Tekst] /S. Gorobchishina, A. Duda // UNCPD, Research Update. - 2017.-№11(763). Retrieved from: http://www.usipr.org.ua/index.php. [in Ukraine]

6. Konvencija Organizacii Obednanyh Nacii proty korupcii [United Nations Convention against Corruption] [Elektron. resurs]. - Retrieved from : https://zakon.rada.gov.ua/laws/show/995_c16. [in Ukraine]

7. Lapshin, S. (2018) Vykoristannja dosvidu E-deklaruvannja krain EC z metoju udoskonalennja zakonodavstva Ukrainy y sferi borotby z korupcieju [Using the E-declaration experience of the EU countries to improve the legislation of Ukraine in the area of anti-corruption] [Tekst] / S.Lapshin // Aktualni problemy syspilno-politychnyh nauk: zbirnik materialiv naukovoi konferencii. - Vinnycja, 2018. - S.9-16.[in Ukraine] 
8. Macokin, A. E. (2018) E-deklaruvannja: njuansy dotrymannja zakonodavchyh norm [E e-declaration: The nuances of compliance with legislative norms] [Tekst] /A. E. Macjukin //Misceve samovrjaduvannja. - 2018. - № 3. -S. 41-46.[in Ukraine]

9. Marchenko, V.Ju. (2017) Elektronne deklaruvannja majnovogo stant chynovnykiv v krainah Evropy cherez pryzmy typiv informacijnogo suspiltva [Electronic declaration of property State officials in Europe through the prism of types of information society] [Elektron. resurs] / V.Ju.Marchenko // Molodyi vchenyi. - 2017. - № 3. - S. 545-548. - Retrieved from : http://nbuv.gov.ua/ UJRN/molv_2017_3_129. [in Ukraine]

10. Novak, A. (2016) Teoretichni osnovy doslidzhennja protydii korupcijnym projavam y systemi publichnogo upravlinnja [Theoretical foundations of the research on countering corrupt manifestations in the public administration system] [Tekst] / A.Novak // Derzhavne upravlinnja ta misceve samovrjaduvannja. - 2016. - Vyp. 1. - S. 29-36. [in Ukraine]

11. Podatkovyi Kodeks Ukrainy [Tax code of Ukraine] // Vidomosti Verhovnoi Rady Ukrainy. - 2011. - № 13-14, № 15-16, № 17. - st. 556. [in Ukraine]

12. Povidomlennja pro pochatok prohodzhennja perevirky vidpovidno do Zakony Ukrainy «Pro ochyshhennja vlady» [Notification of commencement of inspection under the law of Ukraine "on purification of government"] [Elektron. resurs]. - Retrieved from : http://bashtanka.mk.gov.ua/ ua/1416312424/1416560769/1416561730/. [in Ukraine]

13. Pro derzhavnu slyzhby [Tekst]: zakon Ukrainy vid 10.12.2015 № 889VIII[ On the civil service [text]: Law of Ukraine of 10.12.2015 № 889-VIII] // Vidomosti Verhovnoi Rady Ukrainy. - 2016. - № 4. - st. 60. [in Ukraine]

14. Pro Nacionalny policiju [Tekst]: zakon Ukrainy vid 02.07.2015 № 580VIII [On the national Police [text]: Law of Ukraine of 02.07.2015 № 580-VIII] // Vidomosti Verhovnoi Rady Ukrainy. - 2015. - № 40-41. - st. 1970.[in Ukraine]

15. Pro ochyshhennja vlady [Tekst]: zakon Ukrainy vid 16.09.2014 №1682VII [On purification of power [text]: Law of Ukraine from 16.09.2014 no1682VII] // Vidomosti Verhovnoi Rady Ukrainy . - 2014. - № 44. - st. 2978.[in Ukraine]

16. Pro pochatok roboty systemi podannja ta opryljudnennja deklaracii osib, upovnovazhenyh na vykonannja funkcii derzhavy abo miscevogo 
samovrjaduvannja: rishennja Nacionalnogo agentstva z pytan zapobigannja korupcii vid 10.06.2016 № 2 [On the commencement of the system submission and publication of declarations of persons authorized to perform functions of the state or local self-government: The decision of the National Agency for the Prevention of corruption from 10.06.2016 No. 2] [Elektron. resurs]. - Retrieved from : http://zakon5.rada.gov.ua/laws/show/ z0958-16. [in Ukraine]

17. Pro rozjasnennja shodo zastosuvannja okremych polozhen Zakony Ukrainy «Pro zapobigannja korupcii» stosovno zahodiv finansovogo kontrolju: rishennja Nacionalnogo agentstva z pitan zapobigannja korupcii vid 11.08.2016 №3 [On explanations on the application of certain provisions of the law of Ukraine "on prevention of corruption" regarding financial control measures: the decision of the National Agency for the Prevention of corruption from 11.08.2016 №3] [Elektron. resurs]. - Retrieved from : https://nazk.gov.ua/ sites/2019/rozyasnennya_29.12.2018_1.pdf. [in Ukraine]

18. Pro sluzhbu v organah miscevogo samovrjaduvannja [Tekst]: zakon Ukrainy vid 07.06.2001 [On local self-government service [text]: Law of Ukraine of 07.06.2001] - Retrieved from : http://zakon5.rada.gov.ua/laws . [in Ukraine]

19. Pro zapobigannja korupcii [Tekst]: zakon Ukrainy vid 14.10.2014 №1700-VII [On prevention of corruption [text]: Law of Ukraine of 14.10.2014 № 1700-VII] // Vidomosti Verhovnoi Rady Ukrainy. - 2014. - № 49. - st. 2056. [in Ukraine]

20. Pro zapobigannja ta protydij legalizacii (vidmyvannja) dohodiv, oderzhanyh zlochynnym shljahom, abo finansuvannju teroryzmy [Tekst]: zakon Ukrainy vid 14.10.2014 [On prevention and counteraction to legalization (laundering) of income obtained by criminal or financing of terrorism [text]: Law of Ukraine of 14.10.2014 ] .- Retrieved from : http://zakon5.rada.gov.ua/ laws [in Ukraine]

21. Pro zatverdzhennja Porjadku perevirki fakty podannja subektamy deklaruvannja deklaracii vidpovidno do Zakony Ukrainy «Pro zapobigannja korupcii» ta povidomlennja Nacionalnogo agentstva z pitan zapobigannja korupcii pro vypadki nepodannja chy nesvoechasnogo podannja takyh deklaracii: rishennja Nacionalnogo agentstva z pitan zapobigannja korupcii vid 06.09.2016 №19 [On approval of the procedure for verifying the submission of declarations by the subjects in accordance with the law of Ukraine "on prevention of corruption" and 
notification of the National Agency for Prevention of corruption on cases of failure to submit or untimely submission of such declarations: the decision of the National Agency on Corruption Prevention from 06.09.2016 19] [Elektron. resurs]. Retrieved from : https://zakon.rada.gov.ua/laws/show/z1479-16. [in Ukraine]

22. Publichnyi zvit golovy rajderzhadministracii (2019) [Public report of the head of of Rayderzhadministracii] [Elektron. resurs]. - Retrieved from : http://bashtanka.mk.gov.ua/ua/rda/public_zvit/. [in Ukraine]

23. Pihockyi, V. F. (2018) Derzhavnyi finansovyi kontrol [State Financial control] [Tekst] : navch. posib. / V. F. Pihockyi, O. M. Pihocka ; M-vo osvity i nauky Ukrainy, Nac. un-t «Lviv. Politehnika». - Lviv : Vydavnictvo Lviv'koi politehniky, 2018. - 481 s. [in Ukraine]

24. Rjabchenko, T. O. (2017) Elektronne deklaruvannja jak efektyvnyi zasib zapobigannja korupcii $\mathrm{V}$ organah miscevogo samovrjaduvannja [Electronic declaration as an effective tool for preventing corruption in local self-government bodies] [Elektronnij resurs] / T. O. Rjabchenko // Pravovi gorizonty. - 2017. - Vipusk № 5. - S. 14-19 - Retrieved from : http://nbuv.gov. ua/ UJRN/ln_2017_5_4. [in Ukraine]

25. Sheshotova, O. S. (2018) Vidpovidalnist derzhavnyh sluzhbovciv za porushennja zakonodavstva shodo e-deklaruvannja [Responsibility of public servants for violation of legislation concerning e-declaration] [Tekst] / O. S. Sheshotova // Publichne upravlinnja i administruvannja v Ukraini.-2018. - Vyp. № 4. - S. 82-84.[in Ukraine]

26. Shevchuk, O. A. (2014) Derzhavnyi finansovyi kontrol : navch. posib.: [dlja studentiv VNZ] [State financial control ] / O. A. Shevchuk; M-vo osvity i nauky Ukrainy, Nac. bank Ukrainy, Un-t bank. spravy. - Kyiv : UBS NBU, 2014. - 418 s[in Ukraine]

27. Shhirska, V. S. (2019) Kriminalna vidpovidalnist za deklaruvannja nedostovirnoi informacii [Criminal responsibility for declaring unreliable information] [Tekst] / V. S. Shhirska // Naukovyi visnyk Nacionalnoi akademii vnutrishnih sprav. - 2019. - № 3. - S. 59-64.[in Ukraine]

28. Yedynyi derzhavnyi reestr deklaracii osib, upovnovazheniy na vykonannja funkcii derzhavy abo miscevogo samovrjaduvannja [Unified State Register of declarations of persons authorized to perform functions of the state or local self-government] [Elektron. resurs]. - Retrieved from : https://public. nazk.gov.ua/.[in Ukraine] 


\section{Відомості про авторів / Information about the Author}

Малиновська Наталя Леонідівна: Чорноморський національний університет імені Петра Могили: вул. 68 десантників, 10, Миколаїв, 54003, Україна.

Natalia Malynovska: Black Sea National University of Petro Mohyla, 68 Desantnykiv str. 10, Mykolaiv, 54003, Ukraine

\section{ORCID.ORG/0000-0003-0861-603X}

\section{E-mail: chdunatali@meta.ua}

Непомнюща Альона Геннадіївна: Баштанська районна державна адміністрація Миколаївської області, вул.Героїв Небесної Сотні, 37, м. Баштанка, 56101, Україна.

Alona Nepomniushcha: Bashtanka district state administration of Mykolaiv region, Heavenly Hundred Heroes str. 37, Bashtanka, 56101, Ukraine.

E-mail: nvabd@i.ua 